\title{
„Młyny ważne”, ,młyny na wagach”. Przyczynek do genezy nazwy i konstrukcji
}

\section{Elżbieta Kowalczyk-Heyman}

Zbierając materiały do artykułu o młynach Kolna, stolicy historycznego powiatu kolneńskiego (wcześniej nowogrodzkiego) w ziemi łomżyńskiej, korzystałam m.in. z lustracji z 1565 r. W części odnoszącej się do młynów miejskich wybudowanych na płynącej ok. $8-10 \mathrm{~km}$ od miasta Pisie natknęłam się na określenia mtyn na wagach i mtyn ważny ${ }^{1}$. W starszych zapisach mówiących o jednym $\mathrm{z}$ tych młynów, a pochodzących z lat 1471 i 1478, napotkamy również jego nazwę własną: molendinum Waschny i Wassny ${ }^{2}$. Określenia te i nazwy znane są również ze źródeł małopolskich, wielkopolskich i kujawskich, a także z odnoszących się do ziem ruskich, poczynając od schyłku XIII w.

Przystępując do pisania tego artykułu, miałam na celu jedynie wyjaśnienie przyczyny, dla której część polskich podsiębiernych młynów wodnych była nazywana mtyn ważny lub mtyn na wagach. $\mathrm{Z}$ tego powodu nie przeprowadziłam szerokiej kwerendy źródłowej, a ograniczyłam się do kilkunastu przykładów, w których wspomniano takie młyny i które według mnie pozwalają rozstrzygnąć tę kwestię. Może zatem okazać się, że istnieją nieco starsze zapisy poświadczające istnienie tak nazywanych młynów w Polsce.

Najstarszy zapis, do którego dotarłam, powstał w 1286 r. i dotyczył pozwolenia księcia

\footnotetext{
1 Lustracja województwa mazowieckiego 1565, cz. 2, wyd. I. Gieysztorowa, A. Żaboklicka, Warszawa 1971, s. 116-117. W tejże lustracji inne młyny na wagach / ważne odnajdziemy w Wiźnie na Narwi (s. 47) i w Nowogrodzie na Pisie (s. 93).

2 Archiwum Główne Akt Dawnych [dalej: AGAD], Metryka Koronna [dalej: MK] 6, k. 4 i 113, wypisy z kartoteki Stownika historyczno-geograficznego Mazowsza w Instytucie Historii PAN w Warszawie.

3 Kodeks dyplomatyczny Małopolski [dalej: KDMp.], t. 1, wyd. F. Piekosiński, Kraków 1876, nr 112; Z. Mazur, Dwa dokumenty Leszka Czarnego dla dominikanów sandomierskich, „Studia Historyczne”, 12 (4), 1969, s. 609-610. Tu takż o datowaniu tego dokumentu.

${ }_{4}^{4}$ Zbiór dokumentów małopolskich [dalej: ZDM], t. 6, wyd. S. Kuraś, I. Sułkowska-Kuraś, Wrocław 1974, nr 1828; Z. Mazur, Dwa dokumenty, s. 609-610. Tu także o datowaniu tego dokumentu. W tym miejscu warto podkreślić wczesną metrykę sandomierskiego młyna. W Paryżu
}

Leszka Czarnego danego sandomierskim dominikanom na budowę w Sandomierzu młyna na Wiśle. Nie zawiera on wprawdzie określeń mtyn ważny czy mtyn na wagach, a jedynie zapis mówiący o „molendinum pendens et superpendens cum duabus rotis" 3 , ale - jak to się zaraz okaże - jest ważny dla dalszego wywodu. Ten sam młyn w drugim dokumencie tego księcia (z 1287 r.) opisano bowiem następująco: „molendinum pro nobis cum duabus rotis et duplicibus molaribus, quod vulgariter dicitur nawagach". Młyn ten miał być posadowiony w miejscu dawnego młyna łodnego ${ }^{4}$. Fakt ten okaże się istotny dla dalszych rozważań.

Kolejny zapis pochodzi z wydanego w $1380 \mathrm{r}$. dokumentu burgrabiego konińskiego Świętosława, nadającego młynarzowi Więckowi młyn na Warcie pod Koninem: „molendinum dictum Wazny Mlyn de duabus rotis vel si plures commode fieri poterint in fluvio Wartha intermedio villae Curowo et molendinum Jaschkonis molendinatoris in Czarnkowo in districtu Coninensi"

W innym dokumencie - sporządzonym w 1446 r. i odnoszącym się do jednego z młynów poznańskich - odnajdujemy zrównanie obu określeń: „molendinum pendens alias

na Sekwanie moulins pendants wzniesiono po 1296 r., po runięciu Wielkiego Mostu. K. Berthier, Meuniers et moulins, w: La Seine et Paris, ed. B. de Andia, Paris 2000, s. 74 oraz il. na s. 77, na której ukazano ten typ młynów wzniesionych na palach, o kole wodnym umocowanym pod młynicą. Także Paul Benoit i Joséphine Rouillard uważają, że we Francji pierwsze młyny wiszące (hanging mills) pojawiły się dopiero w XIV w. P. Benoit, J. Rouillard, Medieval Hydraulics in France, w: Working with Water in Medieval Europe. Technology and Resource-Use, ed. P. Squatriti, London-Boston-Köln 2000, s. 206-207 i il. 5. Nie mamy jednak pewności, czy konstrukcja sandomierskiego młyna była taka sama.

5 T. Jurek, Kilkanaście niedrukowanych dokumentów wielkopolskich z XIII i XIV w., w: Fontes et historia. Prace dedykowane Antoniemu Gąsiorowskiemu, Poznań 2007, nr 10, s. 108-110 i przyp. 4, w którym badacz ten odwołał się do zapisu w lustracji z 1564-1565 r. o młynie 
Waszny Mlyn"6. Dodajmy jeszcze dokument Zygmunta Starego z 1538 r. dotyczący jednego z młynów Kolna posadowionych na Pisie, wzniesionego przez Macieja Borkowskiego. Opisano go w nim: „molendinum novum pensile alias Vazny"'. W wyciągu z tego dokumentu określono młyn jako „molendinum pensile alias wazny". We wpisie do Metryki Koronnej zapisano natomiast, że Maciej Borkowski „[...] molendinum pensile in fluvio Pisia construxit". W tym samym roku tak samo opisano inny młyn na Pisie - przynależny do Nowogrodu ${ }^{10}$.

Młyny na wagach budowane były również w innych częściach Polski. Oto w 1567 r. odnotowano taki na Pilicy koło dworu biskupów włocławskich w Smardzewicach: „molendinum [...] in fluvio Pilcza na vagach" oraz koło wsi Twarda (Chwarda): „molendinum $[\ldots]$ in fluvio Pilcza na vagach constructum" ${ }^{\prime 1}$. Odnajdujemy je również w XVI w. w Małopolsce. Jednym $\mathrm{z}$ nich był „Młyn na wagach na Wiśle" w Niepołomicach, wzmiankowany w 1565 r. $^{12} \mathrm{~W}$ tym samym czasie odnotowano taki obiekt na Wieprzu: „Młyn na wagach. Jest [...] na rzece Wyeprzu we wsi JKM Skokach, który należy natenczas do Gołębya"13.

Powyższe zapisy mają dla nas ten walor, że pozwalają utożsamić łacińskie molendinum pensile i molendinum pendens $\mathrm{z}$ polskim mtynem ważym, mtynem na wagach. Istotne jest zwłaszcza to, że łaciński rzeczownik pen-

Zowagi Wąsny. W rzeczywistości zapis ten pojawia się w dwóch późnych odpisach rewizji listów z okazji tejże lustracii, zaopatrzonych w błedna datę 1330 r. Należy go oczywiście odczytać jako 'zowią go Ważny'. Por. regest tego dokumentu w: Kodeks dyplomatyczny Wielkopolski [dalej: KDW], t. 6, wyd. A. Gąsiorowski, H. Kowalewicz, Poznań 1982, nr 268. Młyn ten jest identyfikowany z późniejszym młynem klasztornym, wymienionym w oblacie tegoż dokumentu z $1586 \mathrm{r}$. W dokumencie podano, że leżał on między Kurowem a Ozorkowem, ale wydawcy uważają, że informacja jest błędna i powinien to być Czar(n)ków. Tamże, przyp. 2.

6 Digital Library of Wielkopolska (www.wbc.poznan.pl/dibra/docmetadata?id=141509\&from = publication, dostęp: 1 października 2014).

7 AGAD, perg. 626

8 Matricularum Regni Poloniae Summaria [dalej: MRPS], t. 4/3, wyd. T. Wierzbowski, Warszawa 1915, nr 19025.

9 MK 54, k. 353v-354; Inventarium omnium et singulorum privilegiorum, litterarum, diplomatum, scripturarum et monumentorum quaecumque in Archivo Regni in Arce Cracoviensi continentur, wyd. E. Rykaczewski, Berlin-Poznań 1862, s. 356. Czesław Brodzicki, który prawdopodobnie nie miał w ręku żadnego z przywołanych dokumentów dens, -ntis i przymiotnik pensilis, -e oznaczają tyle co 'wiszący, zwisający, zawieszony'14, przy czym drugi termin powiązany jest z łacińskim rzeczownikiem pensa, -ae - 'waga'15. Mamy zatem do czynienia z młynem, który w dosłownym tłumaczeniu określeń łacińskich należatoby nazwać 'wiszącym, zawieszonym'.

Aby kontynuować wywód, należało zatem podjąć dalsze poszukiwania $\mathrm{w}$ źródłach pisanych i w polskiej literaturze przedmiotu mające na celu objaśnienie znaczenia istoty terminów molendinum pensile i molendinum pendens oraz mtyn na wagach i ważny mtyn. Możliwe byłoby to po poznaniu budowy kryjącego się za nimi typu młyna wodnego. Należało też zadać pytanie, czy aby na pewno pod tymi terminami występuje zawsze ten sam typ młyna i czy jego konstrukcja nie ewoluowała w ciągu kilkuset lat młynarstwa wodnego w Polsce.

Początkowo poszukiwania nie dały zadowalających rezultatów. $Z$ uniwersału poborowego z 1579 r. wynikało jedynie, że odróżniano wówczas młyny ważne od innych typów, a zwłaszcza od walnych i łodnych, o czym świadczy zapis: „Młynarze od kół walnych [podsiębiernych - E.K.-H.], dziedzicznych, korzecznych [nasiębiernych - E.K.-H.], lodnych [łodnych - E.K.-H.], ważnych"16.

Najstarsze, pochodzące z XVI-XVII w. polskie prace poświęcone m.in. młynarstwu nie wyjaśniają budowy i zasad działania mły-

błędnie podał, że był to młyn Marcina z Borkowa. C. Brodzicki, Kolno na Mazowszu, Warszawa 1982, s. 65.

10 MRPS, t. 4/3, nr 19019

11 Monumenta Historica Dioeceseos Vladislaviensis, t. 12, Włocławek 1894, s. 9-10.

12 Lustracja województwa krakowskiego 1564, cz. 1, wyd. J. Małecki, Warszawa 1962, s. 74.

13 Lustracja województwa sandomierskiego 1564-1565, wyd. W. Ochmański, Wrocław 1963, s. 244.

14 Słownik łaciny średniowiecznej w Polsce [dalej: Słow. łac.), red. K. Weyssenhoff-Brożkowa, t. 7, z. 2 (53), Kraków 1993, szp. 237, 257. Nie odnotowano w nim tych terminów w odniesieniu do młynów.

15 Tamże, szp. 255. Terminem tym określano np. Wielką i Małą Wagę w Krakowie (pensa magna/maior i pensa nova/minor). Por. niżej s. 65 i 69 oraz Rynek gtówny w Krakowie. Badania 2005-(2006) 2007, red. W. Komorowski, t. 1: Źródła do dziejów zabudowy związanej z handlem we wschodniej części Rynku Głównego w Krakowie, wyd. K. Follprecht, K. Jelonek-Litewka, Kraków 2007, s. 1-45.

16 Volumina Legum, t. 2, Petersburg 1859, s. 192 (k. 983) 
nów ważnych ${ }^{17}$. Dlatego też opisanie ich konstrukcji sprawiało badaczom sporo trudności. Mirosław Frančić skłonny był identyfikować młyny ważne (na wagach) z młynami łodny$\mathrm{mi}^{18}$ i z kołem podsiębiernym, czyli walnym ${ }^{19}$. Osobno opisał młyn posadowiony na palach i uznał, że jego łacińskim odpowiednikiem był molendinum pendens - 'młyn wiszący'. Uważał też, choć bez objaśnienia, że budowanie młynów na palach było niedogodne i że tego typu obiekty występowały tylko na Śląsku. Wiedział wprawdzie o istnieniu wałów kół młyńskich podnoszonych za pomocą łańcucha w zależności od poziomu wody w rzece, ale nie opisał tego mechanizmu i nie zilustrował go zapisami źródłowymi.

$\mathrm{Na}$ dokonane przez Frančicia utożsamienie młynów ważnych z łodnymi mogły mieć wpływ objaśnienia dziewiętnastowiecznych niemieckich wydawców źródeł pisanych. Przykładem jest komentarz Colmara Grünhagena i Konrada Wutkego zawarty w zapisce z 1326 r., a dotyczący „pendens molendinum vulgariter hengilmul" wzniesionego na Odrze koło Oławy. Badacze ci objaśnili go jako Schiffsmühle - 'młyn łodny, pływający'20. Być może wpływ miała też definicja molendinum pendens zaczerpnięta ze słownika Du Cange'a ${ }^{21}$.

Określenie de molendino Pendens zrównane $\mathrm{z}$ niemieckim der Hengil mole odnaj-

17 Np. O. Strumieński, 0 sprawie, sypaniu, wymierzaniu i rybieniu stawów. 1573, wyd. F. Kucharzewski, Kraków 1897, s. 13-14, 34-36; S. Solski, Architekt polski, wyd. J. Burszta, C. Łuczak, Wrocław 1959, S. $158 \mathrm{nn}$.

18 M. Frančić, Technika młynów wodnych w Polsce w XVI i XVII w. „Kwartalnik Historii Kultury Materialnej”, 2 (1-2), 1954, s. 86 90-91; D. Gräf, Boat Mills in Europe from Early Medieval to Modern Times, Dresden 2006. Ostatnia z wymienionych to bardzo bogato ilustrowana praca dostarczająca informacji o wielu odmianach młynów łodnych w Europie. Niestety nie uwzględniono w niej tego typu młynów w Polsce.

19 Porównanie to jest nieadekwatne, albowiem nazwa koło walne odnosi się do sposobu jego napędzania, a nazwa młyn ważny lub na wagach dotyczy sposobu umocowania koła.

20 Regesten zur schlesischen Geschichte, 1316-1326, Hrsg. C. Grünhagen, K. Wutke, Breslau 1898 (Codex Diplomaticus Silesiae, 18), nr 4503.

21 C. du Cange i in., Glossarium mediae et infimae latinitatis, t. 5, Graz 1954 [przedruk], s. 444.

22 Stadtbuch von Posen, Bd. 1, Hrsg. A. Warschauer, Posen 1892, nr 484. Por. też nr 112, 123 i 162.

23 R. Weigand, Deutsches Wörterbuch, Bd. 1: A-K, Giesen 1909, s. 807, 848 dziemy także w księdze radzieckiej miasta Poznania, na przykład pod 1428 r. $^{22}$ Wynika $\mathrm{z}$ niej, że niemieckie hengilmul, hengil mole są kalką łacińskiego terminu pendens i odnoszą się bez wątpienia do młyna wiszącego, bowiem czasowniki hangeln, hangen, hängen i henken oznaczają 'wieszać się, 'wisieć, 'wieszać, 'powiesićn ${ }^{23}$. W tekstach łacińskich młyn łodny zwany był natomiast ,molendinum super naves super Odram”24, „molendinum unum nauium, alias lodny” ${ }^{25}$, „naves molendini, in quibus rote currebant alias lodnye mlynne, na kthorych kola byegaly" 26 , „molendinum navalis [...] in fluvio Warta” ${ }^{27}$, „molendinum navale in fluvio Narew"28.

W tym samym czasie co Frančić termin na wagach inaczej rozumiał i objaśnił Henryk Samsonowicz. Najpierw zrównał młyny na palach $\mathrm{z}$ wiszącymi ${ }^{29}$, a następnie pogląd ten rozszerzył, uznając, że „Młyny na vagach constructum (palowe) były to młynki [...] [stawiane - E.K.-H.] w pewnej odległości od brzegu na palach ${ }^{30}$. Dojście do nich było prawdopodobnie po kładkach czy pomostach ${ }^{31}$. [...] Można je było instalować na mniejszych rzekach (Pilica), gdyż nie unosiły się na wodzie, jak młynki na łodziach. Ten typ występował dość rzadko i tylko w Polsce środkowej, czasem na Kujawach"32. Wypowiedź ta zadomowiła się w kolejnych polskich publikacjach.

24 Schlesisches Urkundenbuch, Bd. 3, Hrsg. W. Irgang, Köln-Wien 1984, nr 433 z 1263 r.; ZDM, t. 6, nr 1828 z 1267 r.

25 Metryka Księstwa Mazowieckiego z XV-XVI w., t. 1: Księga oznaczona nr 333 z lat 1417-1429, wyd. A. Włodarski, Warszawa 1918 (Pomniki Prawa, 5), nr 739 z 1428 r.

26 Akta grodzkie i ziemskie z czasów Rzeczypospolitej Polskiej z Archiwum tzw. Bernardyńskiego we Lwowie [dalej: AGZ], t. 18, Lwów 1903, nr 818 z 1476 r.

27 KDW, t. 2, wyd. I. Zakrzewski, Poznań 1878, nr 1044 z 1324 r.

28 MK 54, k. 354.

29 H. Samsonowicz, Rzemiosto wiejskie w Polsce XIV-XVI w. Warszawa 1954, s. 47. Przywołany w tym miejscu dokument (KDMp., t. 3, wyd. F. Piekosiński, Kraków 1876, nr 632 z 1333 r.) moim zdaniem zawiera wzmiankę o młynie łodnym: „molendinum [...] in ripa seu litore nos hereditarie spectante, de loco ad locum transferendo".

30 Tak skonstruowane zdanie jest nieprecyzyjne. Nie wyjaśnia, czy młyny tego typu stawiano na lądzie, czy też w korycie rzeki, w oddaleniu od jej brzegu. Por. niżej s. 64 i przyp. 40.

31 Pomosty takie widać na przykład na s. 207, il. 5.16 w pracy P. Benoit, J. Rouillard, Medieval Hydraulics. Por. tamże, s. 206. 0 kładkach takich zob. też K. Berthier, Meuniers et moulins, s. 74.

32 H. Samsonowicz, Rzemiosto wiejskie, s. 128. 
Podobne kłopoty z opisaniem młynów na palach miała Zofia Libiszowska, która sądziła, że w takich młynach koło było zawieszone nad wodą, a zanurzone w niej były jedynie łopatki ${ }^{33}$.

Kolejny badacz Stefan Chmielewski słusznie uznał młyny ważne za odmianę podsiębiernych. Zrównał określenia mtyn na palach, mtyn wiszacy i mtyn na wagach, ale nie uzasadnił tego poglądu i nie opisał ich budowy ${ }^{34}$. Całkowitym nieporozumieniem był natomiast fragment wypowiedzi Bohdana Baranowskiego, który wymieniając młyny na palach, uznał, że „miały koła nadsiębierne” 35 .

Kilkanaście lat później badaczka młynarstwa polskiego Maria Dembińska rozważała, czy młyn na palach jest identyczny z młynem na wagach, jednocześnie sugerując, że nazwa mtyn ważny mogła pochodzić od nazwy rzeki Wag, co było z gruntu błędne ${ }^{36}$.

W następnych latach pojawiła się opinia Jerzego Wiśniewskiego, że młyny ważne były przyczepione łańcuchami do potężnych pali na brzegu, z czym nie można się zgodzić - co więcej, nie tłumaczy to ich nazwy ${ }^{37}$. Następnie Jan Górak ponownie utożsamił młyny palowe $\mathrm{z}$ młynami na wagach ${ }^{38}$, również bez objaśnienia ich natury, co prawie dosłownie powtórzyli Grażyna i Jerzy A. Balińscy ${ }^{39}$. Ci ostatni badacze przyjęli również pogląd Samsonowicza mówiący o tym, że młyny te budowano w oddaleniu od brzegu rzeki i wiódł do nich pomost, z tym tylko że - jak sądzę - doszli do wniosku,

33 Z. Libiszowska, Wiejski przemysł spożywczy w województwie tęczyckim w XVI-XVIII wieku, Wrocław 1959 (Studia z Dziejów Gospodarstwa Wiejskiego, 2), s. 519.

$34 \mathrm{~S}$. Chmielewski, Rzemiosto i przemyst wiejski, w: Zarys historii gospodarstwa wiejskiego w Polsce, t. 1, Warszawa 1964, s. 385.

35 K. Baranowski, Przemyst wiejski. 7. Przetwórstwo spożywcze, w: Zarys historii gospodarstwa wiejskiego w Polsce, t. 2, Warszawa 1964, s. 285

36 M. Dembińska, Przetwórstwo zbożowe w Polsce średniowiecznej (X-XIV wiek), Wrocław 1973, s. 125-127 i przyp. 98.

37 J. Wiśniewski, Początek i rozwój nowego osadnictwa w ziemi łomżyńskiej w końcu XIV i w XV wieku, „Studia tomżyńskie”, 1, 1989, s. 67.

38 J. Górak, Młyny wodne na Lubelszczyźnie, „Studia i Materiały Lubelskie", 14, 1997, s. 57.

39 G. Balińska, J.A. Baliński, Młyny ziemi tomżyńskiej, Wrocław 2003, s. 43. Praca poświęcona jest młynom istniejącym od schyłku XIX i w XX w. W odniesieniu do starszego okresu zawiera sporo nieścisłości i błędów. iż były one posadowione na lądzie. Jak bowiem zauważyli, w przeciwnym razie stanowiłyby przeszkody w żegludze. Brak zadowalającego objaśnienia istoty młynów ważnych w polskiej literaturze przedmiotu spowodował, że również autorka tej wypowiedzi kilka lat temu uznała je za mlyny łodne ${ }^{40}$.

Prawie nic nie wnieśli do badanego zagadnienia językoznawcy. $\mathrm{Z}$ nieznanych przyczyn określeń mtyn ważny i mtyn na wagach zabrakło w Stowniku staropolskim ${ }^{41}$, mimo że - jak wykazano wyżej - są one znane co najmniej od schyłku XIII w. Objaśniono je natomiast w Stowniku polszczyzny XVI wieku: „młyn na wagach, ważny - prawdopodobnie na dużych rzekach na palach jak most pontonowy ${ }^{\prime \prime 2}$, co jest już zupełnie niezrozumiałe i było motywowane ówczesnym stanem badań. Nieporozumienie zasadza się na tym, że młyn na palach jest konstrukcją stacjonarną, a młyn pontonowy (łodny) - pływająca.

Nazwa młynów ważnych pojawia się ponadto w kilku pracach toponomastycznych. Oto Teresa Gołębiowska w opracowaniu nazw polskich młynów odnotowała tylko jedną nazwę własną Ważne Mtyny $y^{43}$, występującą w powiecie radomszczańskim, ale ograniczyta się do zaliczenia jej do nazw kulturowych związanych z techniką młynarską ${ }^{44}$. Uściślił to nieco Jerzy Wiśniewski, pisząc ogólnie o typie urządzeń młyńskich, jednak bez ich objaśnienia ${ }^{45}$. Zupełnym nieporozumieniem jest natomiast stwierdzenie odnoszące się do nazwy miejscowej zawarte w jednym z zeszytów $K a-$ talogu zabytków budownictwa przemystowego w Polsce: Ważne Mtyny - ,jak wskazuje sama nazwa, miejscowość ta posiada bogatą trady-

\footnotetext{
40 E. Kowalczyk-Heyman, Początki Kolna, „Rocznik Mazowiecki”, 21, 2009, s. 266, przyp. 33

41 Stownik staropolski (dalej: SSp.), t. 4, z. 4 (23), red. S. Urbańczyk, Wrocław 1964; tamże, t. 10, z. 1 (61), Kraków 1988.

42 Stownik polszczyzny XVI wieku, t. 14, red. M.R. Mayenowa, Wrocław 1982, s. 368.

43 Jest to obecnie nazwa części wsi Stara Brzeźnica, gm. Nowa Brzeźnica, pow. pajęczański, woj. tódzkie.

44 T. Gołębiowska, Nazwy polskich młynów, „Onomastica”, 14 (1-2), 1969, s. 117.

45 J. Wiśniewski, Nazwy młynów w Polsce, „Kwartalnik Historii Kultury Materialnej", 18 (3), 1970, s. 454
} 
cję młynarską" ${ }^{3 / 6}$. Jak rozumiem, autorzy tego opracowania wywiedli nazwę od przymiotnika ważny - 'ważki, znaczący'. Jedynie Ewa Rzetelska-Feleszko, omawiając nazwę wspomnianego wyżej kolneńskiego młyna Ważnego na Pisie, podała objaśnienie: „ważny (:waga), por. mtyn $z$ wagami" $^{\prime \prime}$, nie wyjaśniając jednak, czym były owe wagi. Stwierdzenie to okaże się istotne w dalszych dociekaniach.

Tak jak w przypadku nazw wielu innych młynów, również nazwa mtyna ważnego stała u podstawy przydomka, a następnie nazwiska młynarzy. Dokumentuje to przypadek z Jarosławia i Lwowa. Oto z 1493 r. znani są ,nepothi famosi Martini Vasny, molendinatoris de Iaroslaw". W innym zapisie (z 1500 r.) pojawia się on jako Martinus Vazny: „Martinus Waszny molendinator molendini nostri castri Leopolin ante portam Haliczyensem iacentes", którego nazwisko moim zdaniem utworzono od nazwy młyna Ważnego ${ }^{48}$. Jednak i w odniesieniu do tej nazwy językoznawcy nie uwzględnili takiego objaśnienia. Co więcej, nazwy osobowe utworzone od tej podstawy powiązali jedynie z ogólnosłowiańskim słowem vaga ${ }^{49}$, które jest wszakże zapożyczeniem z języka staro-wysoko-niemieckiego (wāga) i średnio-wysoko-niemieckiego $(w \bar{a} g e)^{50}$. Oznacza to zatem, że nazwy ważny mtyn i mtyn na wagach należy powiązać etymologicznie z apelatywem waga. W konsekwencji pozwala to na wykazanie związku z łacińskim terminem pensa i nazwą molendinum pensile, choć nadal nie tłumaczy istoty działania takich młynów.

$\mathrm{Z}$ przedstawionego przeglądu polskiej literatury przedmiotu wynika, że wśród badaczy nie było zgodności co do przyczyn, dla których część młynów określano jako młyny ważne lub

46 B. Baranowski, W. Baranowski, J. Koliński, Katalog zabytków budownictwa przemystowego w Polsce, t. 4, z. 1: Powiat Pajęczno - województwo tódzkie, Wrocław-Warszawa-Kraków 1967, s. 20. Z opisu trzech tutejszych młynów wynika, że w XIX w. ich młynice zbudowane byty na palach.

47 A. Wolff, E. Rzetelska-Feleszko, Mazowieckie nazwy terenowe do końca XVI wieku, Warszawa 1982, s. 184

48 AGZ, t. 15, Lwów 1891, nr 2307, 3017 (1500 r.). Por. Stownik staropolskich nazw osobowych, t. 6, z. 1, red. W. Taszycki, Wrocław 1981 s. 37 na wagach. Różne też były poglądy co do obszaru występowania takich młynów.

$\mathrm{Na}$ podobną sytuację natrafiamy w literaturze zachodnioeuropejskiej. Oto w przywołanych już wypowiedziach Karine Berthier, Paula Benoit i Joséphine Rouillard terminami moulins pendants i hanging mills określono mtyny posadowione na palach w nurcie rzek o niestabilnym poziomie wody, z kołami wodnymi umieszczonymi między palami pod młynicami (ryc. 1) $)^{51}$. Badacze ci nie uszczegółowili jednak genezy ich nazwy ani nie opisali mechanizmu umożliwiającego utrzymanie koła wodnego w pożądanej pozycji. Wiemy zaledwie tyle, że dokonywano tego za pomocą mechanizmu z czterema korbami. Nie wiemy zatem, czy nazwa takich młynów powstała w związku z posadowieniem ich na palach, czy też motywowało ją podnoszenie i opuszczanie koła wodnego. Z obu prac nie dowiadujemy się również nic o mechanizmie przenoszącym napęd ruchomego koła wodnego na urządzenie mielące.

Zupełnie inaczej budowę interesujących nas młynów omówił Dietrich Lohrmann ${ }^{52}$. Również ten badacz uznał, że wznoszono je na rzekach o zmiennym poziomie wody, a młynice miały w podłodze otwierane drzwi umożliwiające regulowanie wysokości koła wodnego. Jednakże przywołany przez niego piętnastowieczny opis takiego mlyna jest całkowicie różny od opisanych dotąd. Aby to wyjaśnić, przywołam jego treść:

„Sicut enim contingit in certis fluminibus non magnis, quod aque interdum subito crescunt atque decrescunt, construitur in ipsis molendinum tali modo, ut tanquam in statera ipsa casula molendini cum suis rotis atque molis ab aqua suspenditur atque in ipsam etiam ex facili immittitur hoc modo:

49 Stownik etymologiczno-motywacyjny staropolskich nazw osobowych, cz. 1: Odapelatywne nazwy osobowe, oprac. A. Cieślikowa, J. Szymowa, K. Rymut, Kraków 2000, s. 333.

50 'Waga' < Waage, wägen. A. Brückner, Stownik etymologiczny języka polskiego, Warszawa 1957, s. 598-599; L. Moszyński, Geografia niektórych zapożyczeń niemieckich w staropolszczyźnie, Poznań 1954, s. 76.

51 Por. wyżej s. 61-62, przyp. 5.

52 D. Lohrmann, Les moulins d'un ingénieur allemand en Italie vers 1425, w: I mulini nell'Europa medievale, red. P. Galetti, P. Racine, Bologna 2000, s. 305-306. 
Construuntur in terra prope littus columpne due grosse ex lignis sive muro, transversalem trabem fortem sustinentes. Supra quem quidem transversalem trabem alii duo trabes fortes atque
- 'młyna wiszącego', to w przytoczonym opisie nie użyto ani terminu molendinum pendens, ani molendinum pensile. Przy objaśnieniu zasady konstrukcji takiego młyna pojawia się

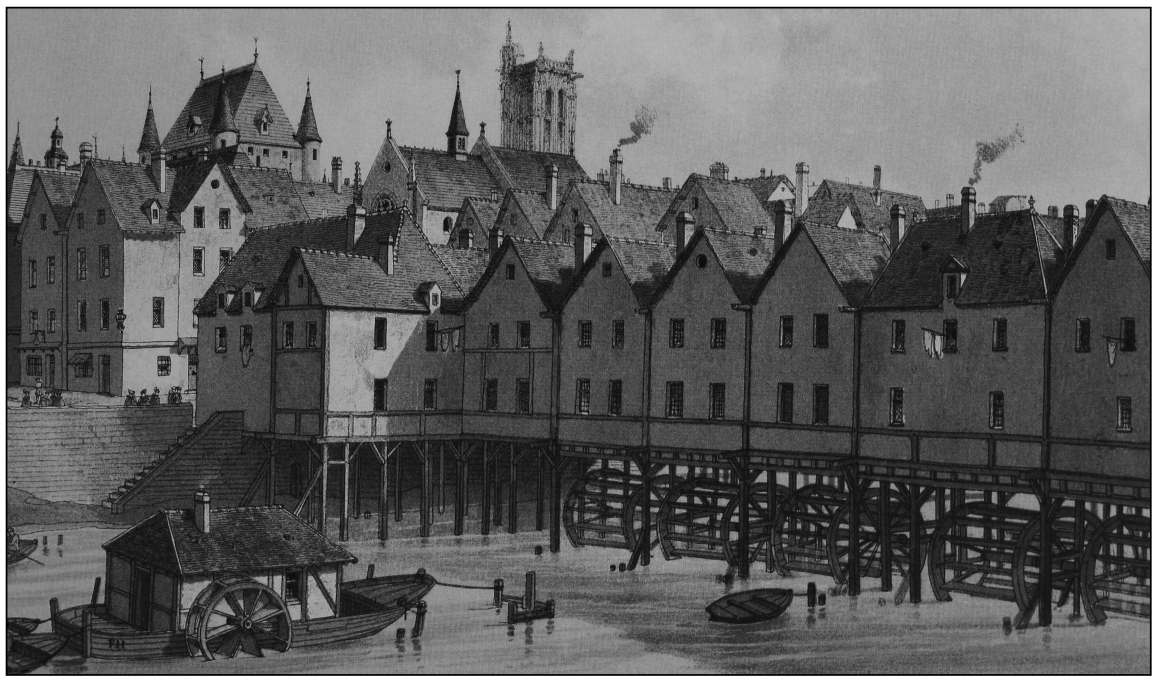

Ryc. 1. Młyny na palach z podnoszonym kotem wodnym umocowanym pod młynica, wzniesione na Sekwanie. Za: F..H. Hoffbauer, „Paris à travers les âges”, Paris 1884 (udostępnione przez Wikimedia Commons; https:/l commons.wikimedia.org/wiki/File\%3APont_de_bois_(Paris).jpg, dostęp: 3 sierpnia 2015)

sufficientes, staterio situ transversaliter mobiles, in longum supra flumen uno capite extenduntur. Quibus etiam in illis capitibus, quibus supra aquam protenduntur, casula perpendiculariter apponitur, rotis atque molis debite per sua necessaria ordinata. Aliis vero capitibus, quibus statera hec ad terram protenditur, cathena seu funis apponitur, qua mediante, per axem ad hoc in terram ordinatam, sublevanti ab aqua atque remittendi casule premisse cum suis necessariis sit copiosa facultas. Huiusmodi etiam statere trabes similiter tecto gubernantur, ne a sole vel pluvia subitam recipiant corruptionem.

Talia enim molendina primo vidi in patria mea in Werdena supra flumen Ruram, ac Florentie supra Arnum, sub Narnia supra Nigram et Luce supra Circhium, prout hec subiecta pictura demonstrat" ${ }^{53}$.

Zwróćmy uwagę na to, że choć Lohrmann uznał, iż jest to opis budowy moulins suspendus

53 Tamże, s. 315, dok. 3. natomiast słowo statera, -ae - 'waga'. Kolejna różnica to informacja, że obiekty te wznoszono na niewielkich rzekach. Przytoczony opis nie jest w pełni jasny, bowiem pomija wiele elementów niezwykle istotnych w tej konstrukcji. Budowę opisanego typu młyna rozpoczynano od wzniesienia na brzegu rzeki dwóch filarów, na których spoczywała mocna, poprzeczna belka. Na niej umieszczano dwie kolejne belki niczym wagę (musiały być do niej ułożone poprzecznie). $\mathrm{Na}$ ich zwisających nad wodą końcach sadowiono młynicę wraz z kołem wodnym i kamieniami młyńskimi. $\mathrm{Na}$ przeciwnych końcach belek mocowano łańcuch lub linę, za pomocą których podnoszono lub opuszczano młynicę z jej wyposażeniem. Cała konstrukcja wraz z owymi belkami była zadaszona.

Konstrukcja ta działała na zasadzie dźwigni dwuramiennej, zwanej tu wagą. $Z$ opisu nie dowiadujemy się jednak, w jaki sposób mocowane były na belce poprzecznej owe dwie, na 
których wznoszono młynicę. Jest to element bardzo ważny ze względu na masę młyna i naprężenia konstrukcji powstające $\mathrm{w}$ trakcie pracy koła wodnego. Punkt podparcia obu belek musiał mieć też jakieś zabezpieczenie (łoże) zapobiegające zsunięciu się ich z belki poprzecznej. Nie opisano również sposobu mocowania łańcucha lub liny utrzymujących młynicę w pożądanym położeniu. Podnoszenie lub opuszczanie jej na belkach dźwigni powodowało zmianę kąta jej położenia (wertykalnego) względem lustra wody. Na skutek tego podłoga młynicy była pochylona, a koło wodne odchylone od pionu, co zmniejszało jego wydajność. W konsekwencji młyn taki mógł pracować przy niewielkich różnicach poziomu wody, bowiem zwiększenie kąta nachylenia dźwigni uniemożliwiałoby pracę koła wodnego i poruszanie się wewnątrz młynicy. Podsumowując, na podstawie powyższego opisu i praw mechaniki można uznać, że tak wznoszone młyny nie były obiektami dużymi.

Lohrmann przywołał też terminy używane na określenie młynów wiszących: francuskie moulin pendant, angielskie suspension mill, łacińskie molendinum pendulum oraz toskańskie molendinum penzulum ze źródeł z XIII-XIV w., a następnie zrównał je z niemieckim określeniem Panstermühle. Identyfikacja moulin pendant z Panster Müble znana również z innych wypowiedzi ${ }^{4}$ - nie jest jednak przyjmowana przez wszystkich badaczy. Oto na przykład Daniela Gräf uznała, że moulin pendant $\mathrm{z}$ kołem wodnym podnoszonym i opuszczanym za pomocą ogromnych śrub był jedynie poprzednikiem Panster

\footnotetext{
54 Por. tez Encyclopedia of the History of Technology, ed. I. McNeil, London-New York 1990, s. 270; W Brochhaus' Konversations-Lexikon zamieszczono definicję: „Panster - hohes, unterschlächtiges Wasserrad, das zwei Mühlgänge treibt". Brochhaus' Konversations-Lexikon, Bd. 12, Leipzig 1908, s. 951.

55 D. Gräf, Boat Mills, s. 16. Również ta autorka nie podała, jak wyglądał taki mechanizm.

56 Wiesław Długokęcki, a za nim Rafał Kubicki, pisząc o nim, nie podali żadnego odniesienia źródłowego ani chronologii pojawiania się te konstrukcji w państwie zakonnym, jak również nie wyjaśnili zasady jej działania. W. Długokęcki, Z dziejów młynarstwa w komturstwie malborskim w XIII-XV wieku, „Rocznik Elbląski”, 12, 1991, s. 50; R. Kubicki, Młynarstwo w państwie zakonu krzyżackiego w Prusach
} w XIII-XV wieku (do 1454 r.), Gdańsk 2012, s. 121.
Müble, który miał osobny mechanizm do podnoszenia i opuszczania koła wodnego ${ }^{55}$. Bez względu jednak na różnice zdań powyższy pogląd umożliwia dalsze rozważania co do natury młynów ważnych.

Konstrukcja kryjąca się pod określeniem Panster Müble znana była już w państwie zakonu krzyżackiego, gdzie jeden z rodzajów koła wodnego nazywano kołem panstrowym ${ }^{56}$ (niem. Panster Räder). Później, u schyłku XVIII w. młyn o takiej konstrukcji zwany był $\mathrm{w}$ Polsce panstromtynem lub mtynem panstro$w_{y m^{57}} \mathrm{i}$ opis jego budowy w polskiej literaturze

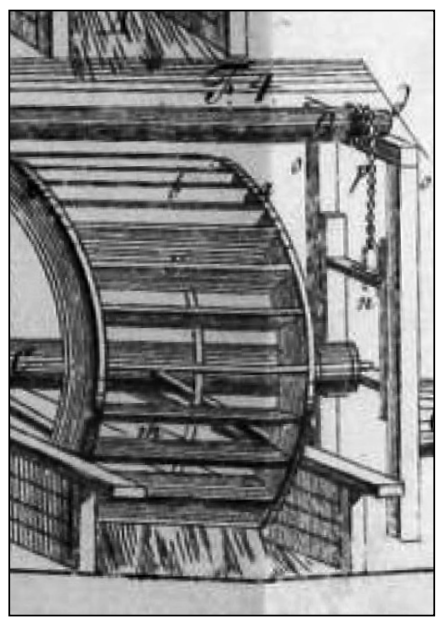

Ryc. 2. Mechanizm podnoszący koło wodne w mtynach panstrowych (widoczna tylko jedna strona mocowania wału koła).

Opis: $n$-krata; 0 - dwa słupy; $p$ - tańcuchy panstrowe; $q$-wat pociągający. Za: J.G. Schneider, „Dalsze poprawione", s. 135-137, tabl. 5, fig. 4

inżynieryjnej poznajemy właśnie w tym czasie. Sześćdziesiąt lat wcześniej taki typ młyna opisano w literaturze niemieckiej ${ }^{5}$.

W polskiej literaturze przedmiotu młyny panstrowe omówił Jan Gotfryd Schneider. Były to młyny stawiane na wielkich rzekach,

57 J.G. Schneider, Dalsze poprawione y pomnożone młyno-budownictwo, cz. 1, Warszawa 1794, s. 135-137. Na młyn o nazwie Panster Mühle (położony nad Rudną, lewym dopływem Odry, obok wsi Rynarcice, gm. Rudna) natrafimy w wydanej ostatnio książce Stownik wsi śląskich w średniowieczu, lecz autorzy nie podali niestety roku jego poświadczenia. D. Adamska i in., Stownik wsi śląskich w średniowieczu, t. 1: Powiat lubiński, Wrocław 2014, s. 160 i tabl. LXVIII.

58 W niemieckiej literaturze technicznej odnajdziemy Panster Räder: np. J.M. Beyer, Theatrum Machinarum Molarium, Leipzig 1735, s. 4463. Panster Mühle pojawia się zaś w publikacjiach W.G. Bleichrodt, Architektonisches Lexikon oder allgemeine Real-Encyklopädie der gesammten..., Weimar 1840, s. 697-688; Pierer's Universal-Lexicon der Gegenwart und Vergangenheit..., Bd. 12, Altenburg 1861, s. 603. 
a w rzeczywistości - jak dowodzą polskie przykłady - również na znacznie mniejszych. Charakteryzowały się one tym, że w zależności od poziomu wody w rzece koło wodne było podnoszone lub opuszczane przez urządzenie zwane Pansterzeug (ryc. 2). Było to możliwe dzięki temu, że bieguny wału koła wodnego spoczywały na dwóch kratach (n) posadowionych między dwoma słupami z fugami $(o)$, po których przesuwano je wraz z wałem. Wał ten wisiał ponadto na łańcuchach $(p)$, które okręcały się na kole wału pociągającego $(q)$. $\mathrm{Na}$ przedłużeniu wału koła wodnego (ryc. 3) zamontowane było koło czołowe (A), mające do 80 palców, które chwytały za wał cewkowy (B).

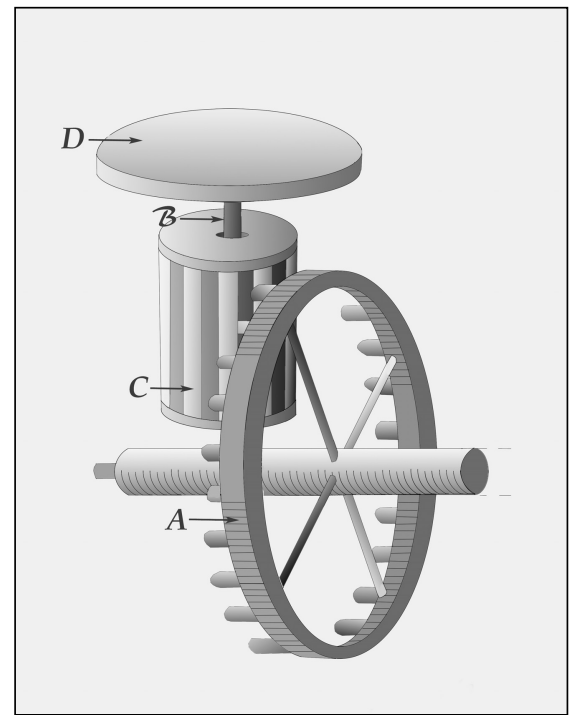

Ryc. 3. Schemat mechanizmu przenoszącego napęd koła wodnego na wat cewkowy i kamienie mtyńskie. Opis: $A$ - koto czołowe, $B$ - wat cewkowy, $C$ - tarcza pociagająca, D - kamienie młyńskie (rys. M. Różycka)

Przy nim z kolei zamontowana była tarcza pociągająca (C) o 36 szczeblach, zwanych też zębami, która przenosiła napęd $\mathrm{z}$ koła czołowego na kamienie młyńskie (D). Zakres przemieszczania koła wodnego w pionie był ograniczony długością szczebli w tarczy pociągającej. Młyn panstrowy bez urządzeń pociągających nazywany był stupny panster (niem. Stock Panster). W tej konstrukcji bieguny wału koła wod- nego $(\mathrm{G})$ spoczywały na belce (ryglu - F) zafugowanej w dwóch słupach (E), którą można było przesuwać $\mathrm{w}$ górę $\mathrm{i} \mathrm{w}$ dół, $\mathrm{w}$ zależności od poziomu wody w rzece (ryc. 4$)^{59}$. Niestety, nie udało się ustalić etymologii słowa panster ${ }^{60}$.

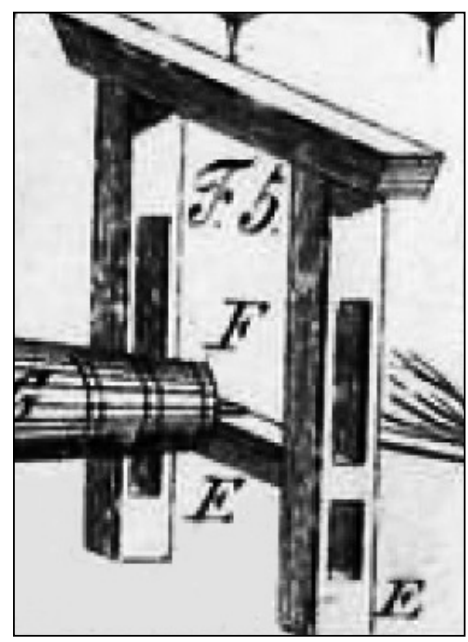

Ryc. 4. Mechanizm podnoszący koło wodne w mtynach o słupnym pansterze (widoczna tylko jednak strona mocowania wału koła).

Opis: $E$ - stupy, $F$ - belka (rygiel), G - bieguny wału koła wodnego.

Za: J.G. Schneider, „Dalsze poprawione”, s. 137, tabl. 5, fig. 5

$\mathrm{Na}$ zamieszczonych w przywołanych pracach rycinach były to młyny wzniesione na brzegu rzek, z kołem wodnym umocowanym z boku młynicy.

W tej części rozważań należałoby zastanowić się, na ile występująca w opisanym nowożytnym młynie panstrowym konstrukcja podnosząca i opuszczająca koło wodne była zbliżona do budowy średniowiecznych młynów ważnych. Polskie nazwy mtyn na wagach, mtyn

\footnotetext{
59 J.G. Schneider, Dalsze poprawione, s. 135-137 i tabl. 5, fig. 4, 5.

60 Dr Maciej Jędrzejewski z Instytutu Filologii Germańskiej Uniwersytetu Warszawskiego wskazał mi możliwość powiązania tego słowa z niemieckim wyrazem Panscher - 'osoba, która się pluszcze lub coś rozcieńcza, aby powiększyć objętość czegoś, jakiegoś płynu'. W omawianym przypadku być może panster należy rozumieć jako nazwę koła wodnego i młyna, które pracują przy podniesionym stanie wody (powiększonej objętości) w rzece. Obecnie zakres znaczeniowy tego terminu zmienił się.
} 
ważny i niemieckie Panster Räder pozwalają przyjąć, że młyn taki miał zapewne również mechanizm pociągający, działający na zasadzie wagi. Łańcuchy podnoszące koło wodne poruszały się na ruchomym wale, a na ich końcach przyczepiano przeciwwagi stabilizujące koło w pożądanej pozycji. Taką przeciwwagę obserwujemy na ukazującej inny typ młyna panstrowego rycinie zamieszczonej $\mathrm{w}$ pracy Johanna Matthiasa Beyera poświęconej młynarstwu ${ }^{61}$. Gdy koło wodne chciano podnieść, minami molendinum pensile i pendens oraz ich niemieckim odpowiednikiem hengilmul i angielskim hanging mill określano młyny wzniesione na palach w nurcie rzeki, z podnoszonym, wiszącym kołem wodnym zamontowanym pod spodem młynicy, a zapewne także z jej boku (ryc. 5). Ponadto do tej kategorii młynów zaliczano również konstrukcję, w której młynicę wraz z kołem wodnym podnoszono i opuszczano na zasadzie działania dźwigni dwuramiennej, zwanej wagą. $\mathrm{Na}$ tym etapie badań nie sposób

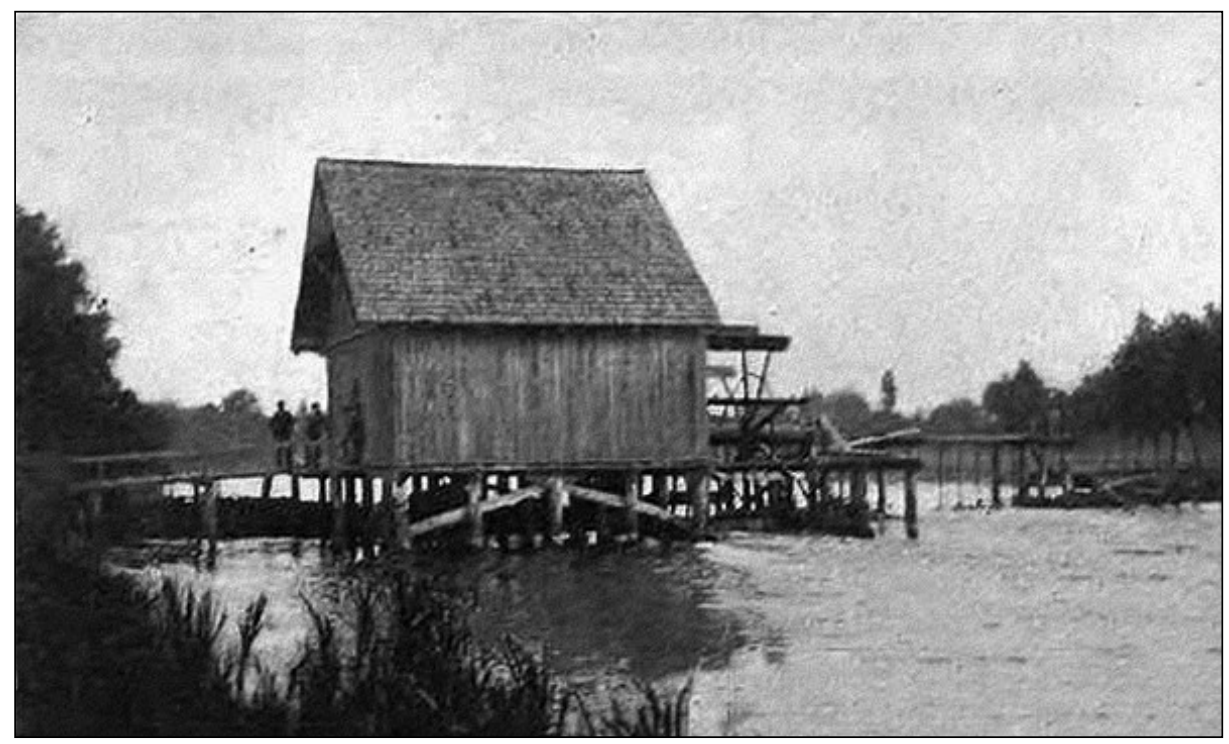

Ryc. 5. Młyn na palach. Za: J. Wnuk-Gugnacki, „Historia wsi Ptaki k/Kolna, część 1” (http://rodzinaspodkolna.blogspot.com/ 2013/11/historia-wsi-ptaki-kkolna-czesc-1.html, dostęp: 15 czerwca 2015)

zwiększano masę przeciwwagi, gdy zaś chciano je opuścić - zmniejszano masę. Zastosowanie tej konstrukcji uniezależniało młynarzy od warunków hydrograficznych, zapewniając ciągłą pracę młyna, oczywiście z wyłączeniem okresu, gdy rzeka pokryta była lodem. Opisana konstrukcja nie była potrzebna na młynach łodnych, albowiem podnosiły się one i opadały wraz z kołem wodnym w zależności od poziomu wody w rzece.

$\mathrm{Na}$ podstawie przytoczonej literatury przedmiotu skłonna jestem uznać, że łacińskimi ter-

61 J.M. Beyer, Theatrum Machinarum, tabl. 16, fig. 1. jednoznacznie stwierdzić, czy polskie terminy mtyn ważny i mtyn na wagach za każdym razem oznaczały tę samą konstrukcję. Pewne jest tylko to, że u ich podstawy stoi zapożyczona $\mathrm{z}$ języka niemieckiego 'waga' i że były one używane synonimicznie do terminów łacińskich. Podstawa słowotwórcza jednego z nich - molendinum pensile - to także 'waga' - pensa.

Na koniec wrócę do powszechnej w omówionych wyżej polskich pracach poświęconych młynarstwu identyfikacji młyna ważnego z młynem na palach ${ }^{62}$. W opracowaniach

62 Por. wyżej, s. 63-67. 
tych można wręcz natrafić na pogląd, iż młyn ważny to młyn na wagach, czyli palach wbitych $w$ dno rzeki. Tym samym wagi błędnie utożsamiono z palami. Inaczej mówiąc, przyjmowano, że nazwy molendinum pensile i pendens oraz mtyn ważny i na wagach pozostawały $\mathrm{w}$ związku z konstrukcją młynicy, a nie koła wodnego. W przeprowadzonej kwerendzie słownikowej nie znalazłam określenia mtyn na palach w żadnej wersji językowej $^{63}$. Wiemy wszakże, że aż do całkiem niedawnych czasów obiekty takie budowano. Przykładem może być jeden z młynów kolneńskich - podsiębierny, położony nad Łabną, prawym dopływem Skrody, który po trzecim rozbiorze Polski, w 1794 r. przeszedł w ręce pruskich osadników Jana i Elżbiety Legatów. W 1807 r., z chwilą rozpoczęcia wyprawy napoleońskiej na Prusy, został on zniesiony przez niezadowolonych z rządów pruskich mieszkańców Kolna. Zniszczono wówczas młyn, rąbiąc koła i podcinając pale, na których był wzniesiony, co spowodowało przewrócenie się młynicy. Pozabierano też wszystkie żelazne części ${ }^{64}$.

W różnego typu źródłach ikonograficznych młyny na palach udokumentowane są często. Powodem wzniesienia całego młyna podsiębiernego lub jego części na palach było przede wszystkim ukształtowanie doliny rzeczki i charakter jej dna. Gdy była płaska i podmokła, nieodzowne było zbudowanie młyna na palach wbitych przy brzegu w dno rzeki. Wówczas niezbędna była kładka łącząca suchy brzeg z młynem, również osadzona na palach. Powodem budowy takiej konstrukcji było także to, że podnosząca się $\mathrm{w}$ rzekach woda mogła nie tylko zalać koło podsiębierne i unieruchomić je, ale również zalać, a nawet znieść młynicę. Także $\mathrm{w}$ przypadku wąskich dolin mniejszych rzek o wyraźnie zaznaczonych, stromych krawędziach część młyna położona najbliżej wody musiała wspierać się na

63 SSp., t. 6, z. 1 (34), Wrocław 1970, s. 8; Stownik polszczyzny, t. 23, Warszawa 1995, s. 25-26; Stow. łac., red. M. Plezia, t. 6, z. 3 (47), Wrocław 1987, szp. 421-423.

64 Za C. Brodzicki, Kolno na Mazowszu, s. 147, 151 palach, aby wyrównać poziom podstawy, na której wznoszono młyn. Podobnie postępowano w przypadku młynów nasiębiernych, gdy woda doprowadzana korytem (młynówką) ${ }^{65}$ spadała na koło posadowione poniżej zbiornika wody.

Ikonografia średniowiecznych młynów francuskich dowodzi, że molendinum pendens wznoszony był na palach w nurcie rzeki. Pozwala to przyjąć, że tak samo były posadowione młyny ważne. Potwierdzały to pozostałości dębowych pali tkwiących w Pisie, w miejscu gdzie istniał kolneński młyn Ważny - w dzisiejszej wsi Kozioł. Pale te były widoczne jeszcze w latach 60. XX w. Wedle informatorów miały średnicę kilkudziesięciu centymetrów ${ }^{66}$. Usunięto je wówczas w związku z projektem skanalizowania tej rzeki - na szczęście poniechanym.

Z przeprowadzonych poszukiwań wynika, że pojawiające się w polskich źródłach pisanych od 2. poł. XIII w. określenia mtyn na wagach i mtyn ważny oraz łacińskie molendinum pensile i molendinum pendens odnosity się do odmiany młynów podsiębiernych, stawianych na rzekach, na których poziom wody ulegał dużym wahaniom. Siłą rzeczy musiały być one wznoszone w całości lub częściowo na palach, w zależności od charakteru doliny rzecznej. Sądzę też, że koła wodne w polskich młynach były umieszczone raczej z boku młynicy, a nie pod nią, a podnoszone i opuszczane na łańcuchach lub linach oraz stabilizowane za pomocą przeciwwag. Te ostatnie zamocowane były na końcach łańcuchów i umożliwiały stabilizację koła w pozycji dostosowanej do poziomu wody w rzece. Nie sądzę natomiast, aby można było jednoznacznie utożsamiać ten typ młyna z młynami na palach, albowiem - jak wykazano - taka konstrukcja była stosowana również w młynach podsiębiernych, mających koło wodne zamontowane na stałe, a nawet w młynach nasiębiernych. Należy zatem uznać,

\footnotetext{
65 Terminem tym określano również boczne koryto cieku lub wykopany kanał, nad którymi budowano młyny.

66 Młyny na Pisie zlikwidowały władze pruskie na pocz. XIX w. dla usprawnienia żeglowności rzeki.
} 
że określenie mtyn na palach nie jest odpowiednikiem nazwy $\boldsymbol{m t y n}$ ważny, $\boldsymbol{m t y n}$ na wagach. Inaczej mówiąc, jakkolwiek młyny ważne były wznoszone na palach, to nie każdy tak posadowiony młyn musiał być młynem ważnym.

Przyjmuję także, że choć terminy łacińskie i ich niemiecki odpowiednik oznaczały $m$ tyn wiszacy, to polskie określenia mtyn ważny, mtyn na wagach powstały od słowa waga i odnosiły się do mechanizmu regulującego położenie

\section{Bibliografia}

\section{Źródła archiwalne i niepublikowane}

Archiwum Główne Akt Dawnych, Warszawa Zbiór dokumentów pergaminowych, perg. 626.

Metryka Koronna, księgi 6 i 54.

Źródła wydane drukiem

Akta grodzkie i ziemskie z czasów Rzeczypospolitej Polskiej z Archiwum tzw. Bernardyńskiego we Lwowie, t. 15, Lwów 1891; t. 18, Lwów 1903.

Digital Library of Wielkopolska (www.wbc. poznan.pl/dibra/docmetadata?id=141509 $\&$ from= publication)

Inventarium omnium et singulorum privilegiorum, litterarum, diplomatum, scripturarum et monumentorum quaecumque in Archivo Regni in Arce Cracoviensi continentur, wyd. E. Rykaczewski, Berlin-Poznań 1862.

Kodeks dyplomatyczny Matopolski, t. 1, wyd. F. Piekosiński, Kraków 1876; t. 3, wyd. F. Piekosiński, Kraków 1876.

Kodeks dyplomatyczny Wielkopolski, t. 2, wyd. I. Zakrzewski, Poznań 1878; t. 6, wyd. A. Gąsiorowski, H. Kowalewicz, Poznań 1982.

Lustracja województwa krakowskiego 1564, cz. 1, wyd. J. Małecki, Warszawa 1962.

Lustracja województwa mazowieckiego 1565, cz. 2, wyd. I. Gieysztorowa, A. Żaboklicka, Warszawa 1971.

Lustracja województwa sandomierskiego $1564-$ 1565, wyd. W. Ochmański, Wrocław 1963. koła wodnego. Nikłą wskazówką sugerująca, że polska nazwa powstała od typu koła wodnego, a nie od konstrukcji młynicy, może być znany z obszaru państwa zakonnego Panster Räder oraz zapis z 1579 r. o kołach $\boldsymbol{w a z i n n y \boldsymbol { c }}^{67}$. Tu trzeba jednak pamiętać, że wielokrotnie w źródłach pisanych młyny określane były jako koła. W dobie nowożytnej, pod wpływem języka niemieckiego, rozpowszechniła się nazwa $m$ tyn panstrowy lub panstromtyn.

Matricularum Regni Poloniae Summaria, t. 4/3, wyd. T. Wierzbowski, Warszawa 1915.

Metryka Księstwa Mazowieckiego z XV-XVI w., t. 1: Ksiega oznaczona $n r 333$ z lat 14171429, wyd. A. Włodarski, Warszawa 1918 (Pomniki Prawa, 5).

Monumenta Historica Dioeceseos Vladislaviensis, t. 12, Włocławek 1894.

Regesten zur schlesischen Geschichte, 1316-1326, Hrsg. C. Grünhagen, K. Wutke, Breslau 1898 (Codex Diplomaticus Silesiae, 18).

Schlesisches Urkundenbuch, t. 3, wyd. W. Irgang, Köln-Wien 1984.

Stownik taciny średniowiecznej $w$ Polsce, t. 6, z. 3 (47), red. M. Plezia, Wrocław 1987; t. 7, z. 2 (53), red. K. Weyssenhoff-Brożkowa, Kraków 1993.

Stownik polszczyzny XVI wieku, t. 14, red. M.R. Mayenowa, Wrocław 1982; t. 23, red. M.R. Mayenowa, Warszawa 1995.

Stownikstaropolski, t. 4, z. 4 (23), red. S. Urbańczyk, Wrocław 1964; t. 6, z. 1 (34), red. K. Nitzsch i in., Wrocław 1970; t. 10, z. 1 (61), red. S. Urbańczyk, Kraków 1988.

Stownik staropolskich nazw osobowych, t. 6, z. 1, red. W. Taszycki, Wrocław 1981.

Stadtbuch von Posen, Bd. 1, Hrsg. A. Warschauer, Posen 1892.

Volumina Legum, t. 2, Petersburg 1859.

Zbiór dokumentów matopolskich, t. 6, wyd. S. Kuraś, I. Sułkowska-Kuraś, Wrocław 1974.

67 Por. wyżej, s. 63, przyp. 17. 


\section{Literatura przedmiotu}

Balińska G., Baliński J.A., Mtyny ziemi tomżyńskiej, Wrocław 2003.

Baranowski B., Przemyst wiejski. 7. Przetwórstwo spożywcze, $\mathrm{w}$ : Zarys historii gospodarstwa wiejskiego $w$ Polsce, t. 2, Warszawa 1964 , s. 282-291.

Baranowski B., Baranowski W., Koliński J., Katalog zabytków budownictwa przemystowego w Polsce, t. 4, z. 1: Powiat Pajęczno-województwo tódzkie, Wrocław-Warszawa-Kraków 1967.

Benoit P., Roullard J., Medieval Hydraulics in France, w: Working with Water in Medieval Europe. Technology and Resource-Use, ed. P. Squatriti, London-Boston-Köln 2000, s. 161-215.

Berthier K., Meuniers et moulins, w: La Seine et Paris, ed. B. de Andia, Paris 2000, s. 74-77.

Beyer J.M., Theatrum Machinarum Molarium, Leipzig 1735.

Bleichrodt W.G., Architektonisches Lexikon oder allgemeine Real-Encyklopädie der gesammten..., Weimar 1840.

Brochhaus' Konversations-Lexikon, t. 12, Leipzig 1908.

Brodzicki C., Kolno na Mazowszu, Warszawa 1982.

Brückner A., Stownik etymologiczny jezyka polskiego, Warszawa 1957.

Chmielewski S., Rzemiosto i przemyst wiejski, w: Zarys historii gospodarstwa wiejskiego w Polsce, t. 1, Warszawa 1964, s. 379-385.

Dembińska M., Przetwórstwo zbożowe w Polsce średniowiecznej (X-XIV wiek), Wrocław 1973.

Długokęcki W., $Z$ dziejów mtynarstwa $w$ komturstwie malborskim $w$ XIII-XV wieku, „Rocznik Elbląski”, 12, 1991, s. 21-62.

Encyclopedia of the History of Technology, ed. I. McNeil, London-New York 1990.

Frančić M., Technika mtynów wodnych $w$ Polsce $w$ XVI i XVII w., „Kwartalnik Historii Kultury Materialnej”, 2 (1-2), 1954, s. 79-103.

Gołębiowska T., Nazwy polskich mtynów, „Onomastica”, 14 (1-2), 1969, s. 81-120.
Górak J., Mtyny wodne na Lubelszczyźnie, „Studia i Materiały Lubelskie”, 14, 1997, s. $45-130$.

Gräf D., Boat Mills in Europe from Early Medieval to Modern Times, Dresden 2006.

Jurek T., Kilkanaście niedrukowanych dokumentów wielkopolskich z XIII i XIV w., w: Fontes et historia. Prace dedykowane Antoniemu Gasiorowskiemu, Poznań 2007, s. 91-116.

Kowalczyk-Heyman E., Początki Kolna, „Rocznik Mazowiecki”, 21, 2009, s. 262-270.

Kubicki R., Mtynarstwo w państwie zakonu krzyżackiego w Prusach w XIII-XV wieku (do 1454 r.), Gdańsk 2012.

Libiszowska Z., Wiejski przemyst spożywczy $w$ województwie tęczyckim $w$ XVI-XVIII wieku, Wrocław 1959 (Studia z Dziejów Gospodarstwa Wiejskiego, 2), s. 503-550.

Lohrmann D., Les moulins d'un ingénieur allemand en Italie vers 1425, w: I mulini nell'Europa medievalem, ed. P. Galetti, P. Racine, Bologna 2000, s. 303-316.

Mazur Z., Dwa dokumenty Leszka Czarnego dla dominikanów sandomierskich, „Studia Historyczne”, 12 (4), 1969, s. 603-610.

Moszyński L., Geografia niektórych zapożyczeń niemieckich w staropolszczyźnie, Poznań 1954.

Pierer's Universal-Lexicon der Gegenwart und Vergangenheit..., t. 12, Altenburg 1861.

Rynek gtówny w Krakowie. Badania 2005(2006) 2007, red. W. Komorowski, t. 1: Źródta do dziejów zabudowy zwiazanej z handlem we wschodniej części Rynku Gtównego $w$ Krakowie, wyd. K. Follprecht, K. Jelonek-Litewka, Kraków 2007, s. 1-45.

Samsonowicz H., Rzemiosto wiejskie w Polsce XIV-XVII w., Warszawa 1954.

Schneider J.G., Dalsze poprawione y pomnożone mtynobudownictwo, cz. 1, Warszawa 1794.

Stownik etymologiczno-motywacyjny staropolskich nazw osobowych, cz. 1: Odapelatywne nazwy osobowe, oprac. Cieślikowa, J. Szymowa, K. Rymut, Kraków 2000.

Solski S., Architekt polski, wyd. J. Burszta, C. Łuczak, Wrocław 1959. 
Strumieński O., O sprawie, sypaniu, wymierzaniu i rybieniu stawów. 1573, wyd. F. Kucharzewski, Kraków 1897.

Weigand R., Deutsches Wörterbuch, Bd. 1: $A-K$, Giesen 1909.

Wiśniewski J., Nazwy mtynów w Polsce, „Kwartalnik Historii Kultury Materialnej”, 18 (3), 1970, s. 449-455.
Wiśniewski J., Początek i rozwój nowego osadnictwa $w$ ziemi tomżyńskiej $w$ końcu XIV i wXV wieku, „Studia Łomżyńskie”, 1, 1989, s. 19-107.

Wolff A., Rzetelska-Feleszko E., Mazowieckie nazwy terenowe do końca XVI wieku, Warszawa 1982.

\section{"Scales Mills" or "Mills on Scales". A Contribution to the Origin of the Notion and the Physical Structure}

\section{Summary}

So far no satisfactory explanation has been provided in the Polish literature devoted to milling concerning the mills called scales mills or mills on scales. The attempts undertaken identified this kind of mills with watermills or, more often, mills on stilts. The author of the present article is of a different opinion as on the basis of written sources - she identified those mills with the ones which were parallelly and simultaneously used with their medieval Latin names of molendinum pensile and molendinum pendens as well as the German name
Panster Mühle, and which were characterized by a water wheel raised and lowered on chains or ropes, depending on the changing water level in rivers. The Polish name of such mills was derived by the author from the scales (counterbalance) stabilizing the water wheel in the desired position. At the same time, the author believes that such mills, as a whole or in part, were placed on stilts for obvious reasons but she also notices that other types of mills were raised on stilts too.

Słowa kluczowe: młynarstwo, onomastyka, konstrukcja młyna wodnego, średniowiecze

Keywords: milling, onomastic, water mill's construction, Middle Ages

prof. dr hab. Elżbieta Kowalczyk-Heyman - zatrudniona w Instytucie Archeologii Uniwersytetu Warszawskiego. Specjalizuje się głównie w średniowiecznych systemach obronnych, kształtowaniu granic, geografii osadnictwa i toponomastyce (e-mail: ekowalczyk@uw.edu.pl) 